\title{
The Formation of Tetracycline in Date Medium by Mutants of Streptomyces aureofaciens Induced by Nitrosogiuanidine.
}

\author{
E. S. Ahmed ${ }^{1}$ and Z. W. Sharawi ${ }^{2}$. \\ 1- Department of Cell Biology, National Research Center. Cairo, Egypt. \\ 2- Department of Biology. Faculty of Science, King Abdulaziz University. \\ Jeddah, Saudi Arabia.
}

\begin{abstract}
The present study deals with the genotoxicity of Nitrosoguanidine (N.T.G.) - a chemical mutagen- which was employed to induce auxotrophic mutations in the haploid wild type of bacteria Streptomyces aureofaciens strain NCIMB 8234.

An increase in exposure time to the mutagen and dose of this mutagen led to a decrease in the survival percentage and increase in the percentage of mutation. The mutants were cultured in synthetic date fermentation medium, which contained Barni date-coat sugar extract as a carbon source. The following parameters were determined: final $\mathrm{pH}$, medium quantity, and microbial cell biomass. All of the five mutants produced less antibiotic titers than the initial organism this was noticed after measuring the inhibition zone of each created for Staphylococcus aureus as a gram-positive pathogenic bacterium and Escherichia coli as a gramnegative pathogenic bacterium.
\end{abstract}

\section{Introduction:}

In the past, bacteria were the most important cause of disease and mortality among humans. The introduction of antibiotics in human medicine has markedly reduced the impact of bacterial diseases on human mortality.

Antibiotics are substances produced by living organisms, which are able to kill or inhibit the growth of microorganisms. According to the literal sense of the word, substances produced synthetically (e.g. sulfonamides or quinolones) Prescott and Baggot (1994) should not be termed antibiotics, and the use of a broader term (i.e. antimicrobial agent) would be more appropriate to indicate the complex of all substances having a harmful effect on microorganisms. However, the term antibiotic is used throughout the present report as a synonym of antimicrobial agent.

Antibiotics are also selectively toxic substances as they affect pathogenic microorganisms more adversely than the host. The degree of selective toxicity depends on the specific mechanisms of action of the drug. The most selective agents are those affecting structures (e.g. cell wall) or functions (e.g. folic acid synthesis) present only in prokaryotic cells. The less selective antibiotics are those affecting protein (e.g. tetracyclines) or nucleic acid synthesis (e.g. quinolones), which are essential functions for both prokaryotic (bacteria) and eukaryotic cells (the host). Tetracyclines are one of the cheapest classes of antibiotic available, and their cost in real terms is declining due to improved manufacturing technology Finch (1997). The pricing structure makes them particularly attractive for use in developing nations Furthermore; the HIV Meeting 2000 suggested the use of tetracyclines to reduce bacterial sexually transmitted diseases in the developing world. Col and O'Connor (1987). Tetracycline efficiency exists in inhibiting protein synthesis by 
preventing amino acyl- tRNA from uniting with the Bacterial ribosome. (Riesbeck et al., 1990).

In 1948 aureomycin (chlortetracycline) was isolated by duggan as a metabolite of the actinomycetes species Streptomyces aureofaciens. This was the first antibiotic of the tetracycline group. Chopra and Roberts (2001).

Studies on the genetics of Streptomyces aureofaciens, the producer of chlortetracycline, have shown that over 300 genes are involved! With such a large number of genes, regulation of antibiotic biosynthesis is obviously quite complex. Unknown. Streptomyces have other important role in the carbon cycle because they analyze what has left in soil like lignocellulose and chitin. (Bentley et al;2002).

Nitrosoguanidine (NTG) is an alkalyting agent which is known for it's mutant effect and induced DNA strand breaks in various organs of rats treated in vivo.; induced chromosomal aberrations and micronuclei in bone-marrow cells of mice it also induced chromosomal aberrations, sister chromatid exchanges, DNA strand breaks and unscheduled DNA synthesis in human and rodent cells in vitro and induced mutation in cultured rodent cells. It gave positive results in several assays for cell transformation.( Wang et al; 2003).

The present study utilizes Bacteria Streptomyces aureofaciens as test organism that is frequently used in this kind of research. Being the antibiotic (chlortetracycline) producer, we also induce auxotrophic mutation that can be investigated easily in $S$. aureofaciens which can also affect the antibiotic production in the organism by increasing or decreasing it.

The purpose of this study is to test the effect of Nitrosoguanidine on the antibiotic production in S. aureofaciens.

\section{Materials and Methods}

The test strain of $S$. aureofaciens was in the haploid stage of NCIMB 8234, which was obtained from Dr.Mohammad Gurban Geshari from Microbiology department who obtained it from National Collections of Industrial, Food and Marine Bacteria LTD. England. Many media were used such as the complete medium for culturing and maintaining the wild type. Czapek Dox agar medium was used as a minimal medium for the detection of auxotrophic mutants. Fermentation medium was used for enhancing the antibiotic production of the organism. Nutrient agar medium was used to culture Staphylococcus aureus and Escherichia coli.

Complete and minimal media cultures were incubated in darkness at $33.7^{\circ} \mathrm{C}$. They were replicated by inoculating the desired cultures in 25 positions in agriculture solid template medium, then replicated simultaneous of inoculants via agriculture 26-pens replicator devise.

\section{Optimal concentration:}

Test of genotoxicity was made by preparing dense cellular suspensions of the wild type strain. Spore suspensions were prepared from growth on Sporulation medium. NTG solutions were made by dissolving $(0.005,0.01$ and0.02 gm) NTG in $5 \mathrm{ml}$ distilled and sterilized water. Each concentration was added immediately to 5 $\mathrm{ml}$ of spore suspension under continuous shaking. These concentrations were used for testing the induction of auxotrophic mutations in $S$. aureofaciens and comparing the perfect concentration that gives more mutants with more survivals. Oneml sample of this mixture was immediately diluted in $9 \mathrm{ml}$ sterile water to serve as untreated control this diluted sample was also diluted in $9 \mathrm{ml}$ sterile water and this was repeated for about 5 times. Subsequent samples were taken at 15, 30, 45 and 60 min. Samples containing about 100 spores per milliliter were spread on complete medium $(\mathrm{CM})$ plates and incubated for 4 days at $33.7^{\circ} \mathrm{C}$. The number of germinated spores was determined at the end of the incubation period in each plate and the number of survivals was determined. Detection of mutants was done by the total isolation procedure. A random samples of growing cells which survived at each interval was inoculated on (CM) plates (26/plate) and 
incubated for 4 days at $33.7^{\circ} \mathrm{C}$. Each of these plates served as template and it was in turn replicated on minimal medium (MM) plates to detect auxotrophic mutants. These replicates were incubated for 4-5 days. Auxotrophic mutants are those which failed to grow or showed a slightly growth of the mycelia on (MM) after incubation.

At each interval the percentage of auxotrophic mutants was determined. The optimal dose that induced the largest possible number of mutants with the largest possible number of mutants at the same time was also determined.

The survival percentage was scored by counting the growing cells after 4 days of incubation: Survival percentage

$$
=\frac{E \times 100}{C}
$$

Where $\mathrm{E}=$ the total number of grown cells in each treatment.

$\mathrm{C}=$ the total number of grown cells in control. Statistically analysis was used to score linear regression to ensure the linear relationship between the exposure period to the mutagen and survival percentage and between the concentration of mutagen and the percentage of mutations.

\section{Determination of mutants:}

Characterization of mutant was done by isolating mutants on (CM) to serve as templates to be replicated on the following supplemented minimal media:

1. $(\mathrm{MM})+$ casein + vitamins + RNA

2. $(\mathrm{MM})$ - casein + vitamins + RNA

3. $(\mathrm{MM})+$ casein + vitamins - RNA

4. $(\mathrm{MM})+$ casein - vitamins + RNA

5. (MM) - casein - vitamins - RNA

A colony which failed to grow on any of either 2,3 or 4 requires the chemical missing from that medium. The auxanographic technique was used to specify the particular nutritional requirement of each mutant. $1 \mathrm{ml}$ cell suspension of mutant was mixed with cooled (MM) in dishes and left to solidify. A few crystals of nutrients to be tested were placed at marked positions around the periphery of the plate. Each mutant grew on the immediate vicinity of the nutrient it required after 4 days of incubation.

\section{Antibiotic production:}

The fermentation medium was prepared and supplied with Barni date-coat sugar extract as a carbon source according to Abou- Zeid et al. (1993) method ; the initial $\mathrm{pH}$ of the medium was adjusted to 6.0. The medium was portioned into Erlenmeyer flasks (capacities $250 \mathrm{ml}$ ), each flask containing $50 \mathrm{ml}$ of the medium. The flasks were plugged with cotton and sterilized. They were inoculated with $1 \mathrm{ml}$ inoculum's of each mutant (3 flasks/mutant) the requirement of each mutant was added according to standard concentrations, the wild type was used as control for comparison. The flasks were placed on a rotary shaking incubator (120rpm) at $30^{\circ} \mathrm{C}$ for 144 hours. At the end of the fermentation period, the following parameters were determined: final $\mathrm{pH}$, microbial cell biomass, resulted media amount, and tetracycline production efficiency as in Abou- Zeid et al. (1991) method.

\section{Results and Discussion}

\section{Optimal concentration:}

The reason of treating $S$. aureofaciens spores with NTG because it had the best effect on creating auxotrophic mutants with higher production of antibiotic traits between other chemical mutagens such as: Hydrogen peroxide ( $\mathrm{H} 2 \mathrm{O} 2)$, and Nitrous acid (HNO2). (Baeshin et al;1992).

The results of treating the spores of $S$. aureofaciens with NTG for different times with its effects on survivors and auxotrophic mutants percentage are shown in table 1. The percentage of survivors decreased linearly as time of exposure increased for the concentration 0.005 . Only one auxotrophic mutation appeared in the exposure time: 45 mins. As the curve in figure. 1 shows the reversal relationship between the exposure time and the survivals percentage, whereas the weak relationship between the exposure time and auxotrophic mutants percentage is shown in figure 2 .

The results in table 2. Show the effect on survival percentage and auxotrophic 


\section{E. S. Ahmed \& Z. W. Sharawi.}

percentage after treating $10 \mathrm{ml}$ suspension of $S$. aureofaciens spores with $0.01 \mathrm{gm}$ NTG. As the curve in figure. 3 shows the reversal relationship between the exposure time and the survivals percentage, while figure 4 shows the relationship between the exposure time and the auxotrophic mutants percentage. Two mutants were isolated the first at 30 mins. and the second at 60 mins.

The results in table 3. Show the effect on survival percentage and auxotrophic percentage after treating $10 \mathrm{ml}$ suspension of $S$. aureofaciens spores with $0.02 \mathrm{gm}$ NTG. As the curve in figure.5 shows the reversal relationship between the exposure time and the survivals percentage, while figure 6 shows the relationship between the exposure time and the auxotrophic mutants percentage. Two mutants were isolated, the first at $15 \mathrm{mins}$. and the second at $60 \mathrm{mins}$.

The results in table 4. Show the effect of NTG concentrations on survival rate and auxotrophic rate after. As the curve in figure 7 shows the reversal relationship between concentration and survival rate percentage, while figure 8 shows the relationship between concentration and auxotrophic mutants rate percentage. The total isolation procedure is shown in figure 9 that was used to determine the mutant colony and isolate it.

The results above indicated that the optimal NTG concentration was $0.02 \mathrm{gm} / 10 \mathrm{ml}$, whereas $0.0075 \mathrm{gm} / 10 \mathrm{ml}$ was the optimal concentration in Baeshin and Sabir study (1984) on Aspergillus terreus. Baeshin et al. (1987) had also determined the NTG optimal concentration on Saccharomyces cerevisiae $0.005 \mathrm{gm} /$ liter.

The results also indicated that survival percentage had reversal relationship with exposure time and concentration of NTG that agree with Fincham et al. (1979) results.

\section{Determination of mutants:}

Determination of auxotrophic mutant requirements was listed in table 5 that shows most of the mutant affects were on those genes that control Vitamins synthesis, Amino acid synthesis then Nitrogen bases synthesis that were the least affected genes.
As figure 10 shows the tiny growth of a mutant strain after supplying the minimal medium with some vitamin crystals, the procedure was repeated using amino acids and Nitrogen bases. These results did not agree with Baeshin and Sabir (1984) study about NTG affect on Aspergillus terreus which indicated that Amino acids were the most required after mutation, this may refer to the differences between the two microorganisms used in each experiment.

The following procedure was used for giving symbols to the mutant strain:

1. The first 2 or 3 letters were taken from the requirement as Alanine $\rightarrow$ Ala.

2. The mutagen used -Nitrosoguanidinefirst letter "N" was used after the requirement letters.

3. The number in the fourth "thousands" category indicated the NTG concentration as $1=0.005,2=0.01, \&$ $3=0.02$.

4. The number in the third "hundreds" category indicated the exposure time by minutes as $1=15,2=30,3=45, \& 4=60$.

Finally, the numbers in the first and second categories indicated the mutation colony number between 26 inoculants in the inoculated dish by the replicator.

\section{Antibiotic production:}

The mycelium weight was measured after incubating mutant strains in the synthetic fermentation medium that used the date lash as the main Carbon source which showed better antibiotic production than using the Glucose as the main Carbon source which was also indicated by AbouZeid et al. (1992). Then every medium was filtered in a filter-sterilized paper and dried by the dry-heat oven as it shown in figure 11.

Filtered discs were steeped in the infiltration media to use it in determining antibiotic production for each mutant strain and comparing their production with the prototroph type (control) by measuring the inhibition zone created by each on a dish lined with Staphylococcus aureus as a Gram positive pathogen and Escherichia coli as a Gram negative pathogen shown in figure 12. All these results were listed in 
table 6, which indicated that synthetic fermentation medium of the control was more acidic (lower $\mathrm{pH}$ ) than the other mutant strains after incubation; as the dry biomass weighted more in the control than it did in the other mutant strains where was the infiltrated quantity less in the control than the other mutant strains. Finally, the inhibition zone was larger in the control than the mutant strains which indicated that the mutant strains produced less antibiotic titers than the control (prototroph type); these results agree with one of the three mutant categories studied by Baeshin et al. (1992) after studying the NTG affect on Oxytetracycline production in Streptomyces rimosus; as the other two categories produced more and same antibiotic titer than the parental strain (control). They also agree with Dairi et al. (1995) study when discovering the NTG affect on Streptomyces aureofaciens strain NRRL 3203 that produced $90 \%$ less antibiotic titers than the prototroph (parental strain). In another study on the combined effect of nitrosoguanidine and UV-beams resulted in the obtaining of 27 variants which exceeded activity of strain Streptomyces aureofaciens
T633 noticed the differentiation in the colonies phenotype which had 30-35\% better antibiotic production titers than the prototype and was affectively producing through 7-10 generations Stryzhkova et al. (2002). Landomycin-deficient mutants (24) were obtained under the effect of nitrosoguanidine on the strains 3-1 and RSp2 of Streptomyces globisporus 1912, high active procedures of polyketide antibiotic landomycin E. Matseliukh et al. (2003). Another study on increasing biosynthesis of avermectins of Streptomyces avermitilis UCM Ac 2161 under the effect of NTG, showed selected the variants with activity 5-6 times as high as that of the initial strain. Petruk et al.(2004).In a similar study to Stryzhkova's, conventional mutagenesis (UV irradiation and exposure to NTG) were used to produce and regenerate protoplasts, aiming at increasing the antibiotic activity of a Streptomyces fradiae strain producing tylosin, the most active variants were produced by a combined exposure to UV and NTG as unstable inheritance of the trait of increased tylosin production was demonstrated. Liutskanova et al. (2005).

Table1. The survival percentage and the auxotrophic mutants produced from treating $S$. aureofaciens spores with $0.005 \mathrm{gm} / 10 \mathrm{ml}$ concentration of NTG.

\begin{tabular}{|c|c|c|c|c|c|}
\hline $\begin{array}{c}\text { Exposure time } \\
\text { (min) }\end{array}$ & \multicolumn{2}{|c|}{ Survivors } & Number of colonies & \multicolumn{2}{c|}{$\begin{array}{c}\text { Auxotrophic mutants } \\
\text { No. }\end{array}$} \\
\hline 0 & 215 & 100 & 156 & 0 & 0 \\
\hline 15 & 210 & 98 & 156 & 0 & 0 \\
\hline 30 & 196 & 91 & 156 & 0 & 0 \\
\hline 45 & 188 & 87 & 156 & 1 & 0.6 \\
\hline 60 & 85 & 39 & 78 & 0 & 0 \\
\hline Total & 894 & & 702 & 1 & \\
\hline
\end{tabular}


E. S. Ahmed \& Z. W. Sharawi.

Fig.1. The relationship between the exposure time and the survivors percentage after treating $10 \mathrm{ml} S$. aureofaciens spore suspension with $0.005 \mathrm{gm}$ NTG.

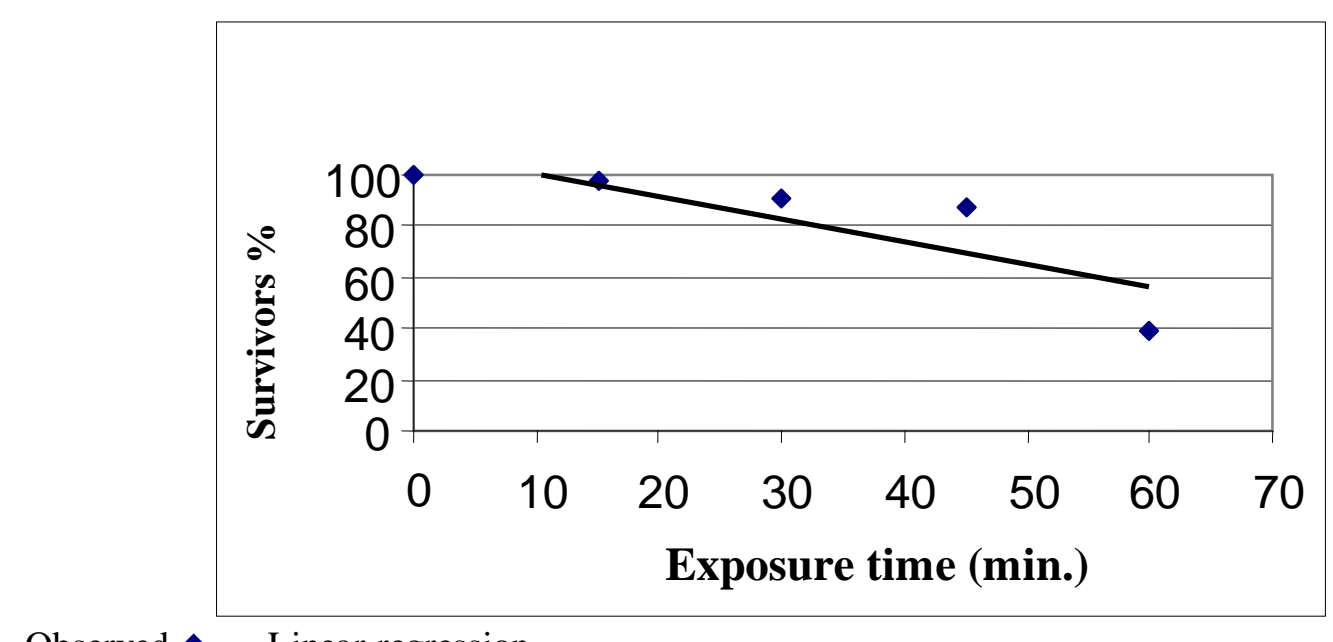

Observed $\bullet \quad$ Linear regression

Fig.2. The relationship between exposure time and auxotrophic mutants percentage produced from treating $10 \mathrm{ml}$ spore suspension $S$. aureofaciens with $0.005 \mathrm{gm}$ NTG.

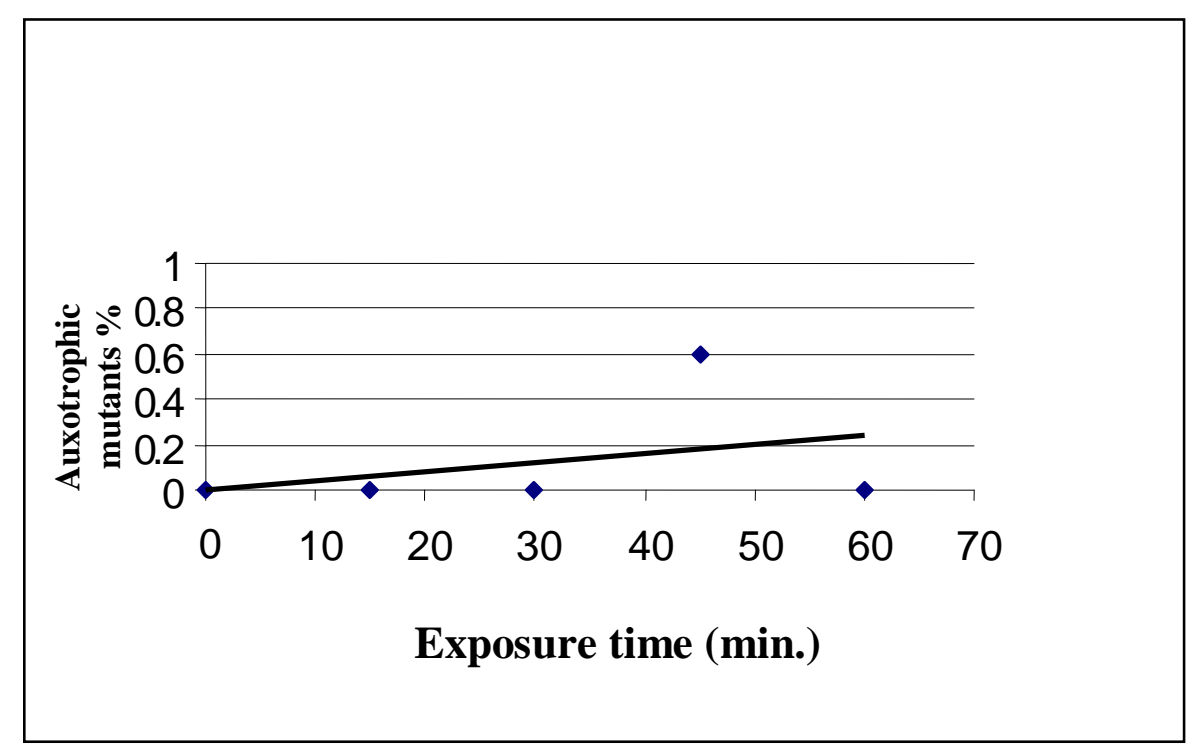

Observed

Linear regression 
Table2. The survival percentage and the auxotrophic mutants produced from treating $S$. aureofaciens spores with $0.01 \mathrm{gm} / 10 \mathrm{ml}$ concentration of NTG.

\begin{tabular}{|c|c|c|c|c|c|}
\hline \multirow{2}{*}{$\begin{array}{c}\text { Exposure time } \\
(\mathrm{min})\end{array}$} & \multicolumn{2}{|c|}{ Survivors } & \multicolumn{2}{c|}{$\begin{array}{c}\text { Number of colonies } \\
\text { tested }\end{array}$} & \multicolumn{2}{c|}{$\begin{array}{c}\text { Auxotrophic mutants } \\
\text { No. }\end{array}$} \\
\hline 0 & 929 & $100 \%$ & 338 & 0 & 0 \\
\hline 15 & 677 & $73 \%$ & 312 & 0 & 0 \\
\hline 30 & 583 & $63 \%$ & 234 & 1 & 0.4 \\
\hline 45 & 491 & $53 \%$ & 234 & 0 & 0 \\
\hline 60 & 456 & $49 \%$ & 234 & 1 & 0.4 \\
\hline Total & 3136 & & 1352 & 2 & \\
\hline
\end{tabular}

Fig.3. The relationship between the exposure time and the survivors percentage after treating $10 \mathrm{ml} S$. aureofaciens spore suspension with $0.01 \mathrm{gm}$ NTG.

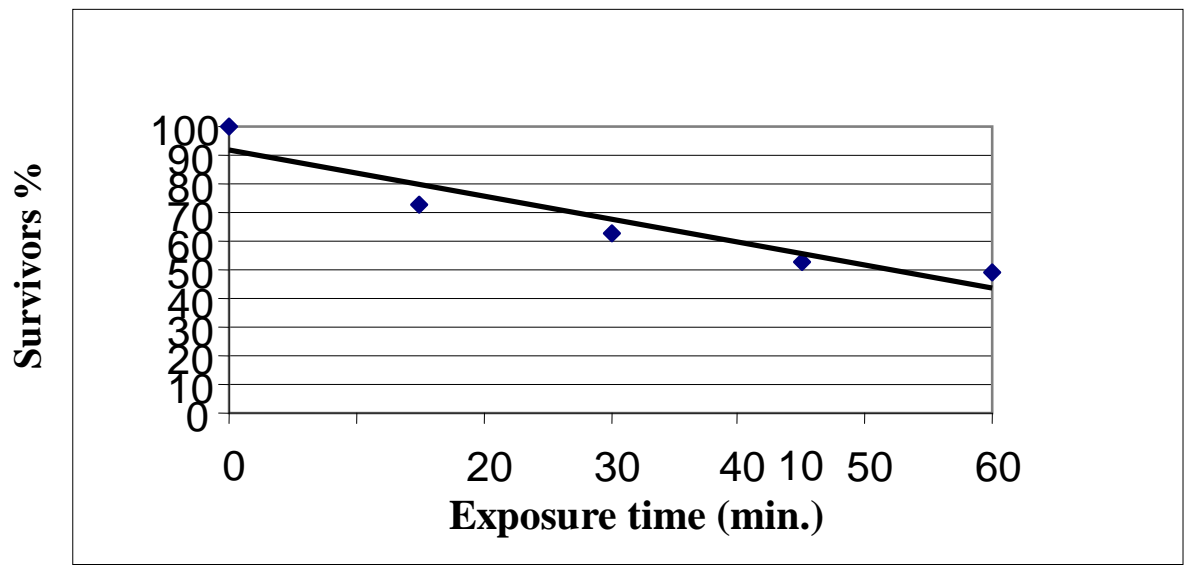

Observed $\quad$ Linear regression

Fig.4. The relationship between exposure time and auxotrophic mutants percentage produced from treating $10 \mathrm{ml}$ spore suspension $S$. aureofaciens with $0.01 \mathrm{gm}$ NTG.

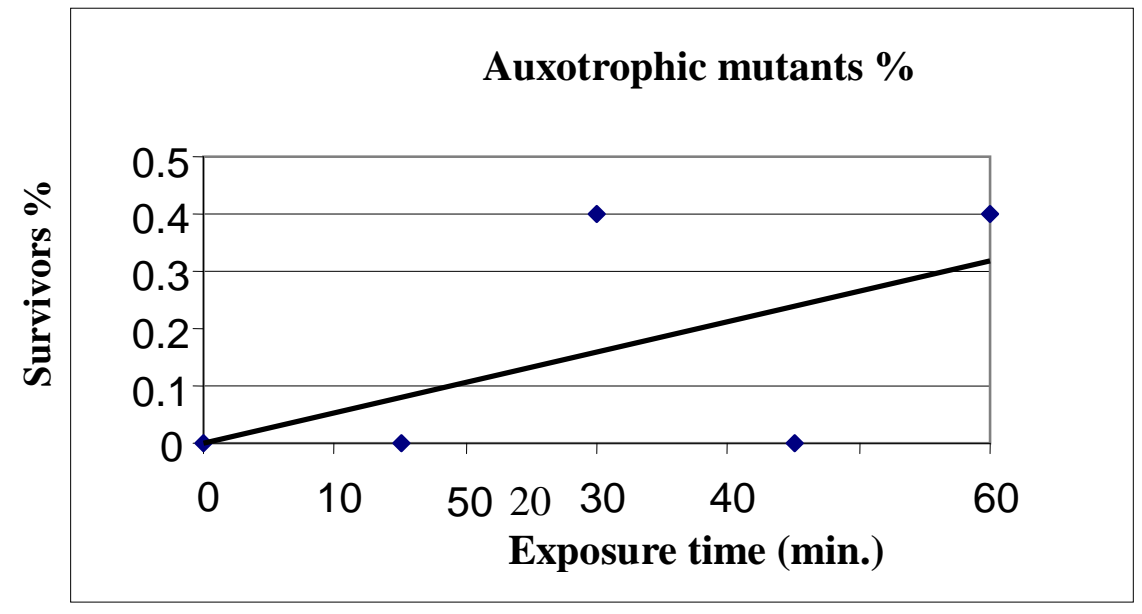

Observed $\bullet \quad$ Linear regression 
Table3. The survival percentage and the auxotrophic mutants produced from treating $S$. aureofaciens spores with $0.02 \mathrm{gm} / 10 \mathrm{ml}$ concentration of NTG.

\begin{tabular}{|c|c|c|c|c|c|}
\hline $\begin{array}{c}\text { Exposure time } \\
\text { (min) }\end{array}$ & \multicolumn{2}{|c|}{ Survivors } & $\begin{array}{c}\text { Number of colonies } \\
\text { No. }\end{array}$ & \multicolumn{2}{c|}{$\begin{array}{c}\text { Auxotrophic mutants } \\
\text { No. }\end{array}$} \\
\hline 0 & 163 & 100 & 130 & 0 & 0 \\
\hline 15 & 110 & 67 & 78 & 1 & 1.3 \\
\hline 30 & 104 & 64 & 78 & 0 & 0 \\
\hline 45 & 101 & 62 & 78 & 0 & 0 \\
\hline 60 & 89 & 55 & 78 & 1 & 1.3 \\
\hline Total & 567 & & 442 & 2 & \\
\hline
\end{tabular}

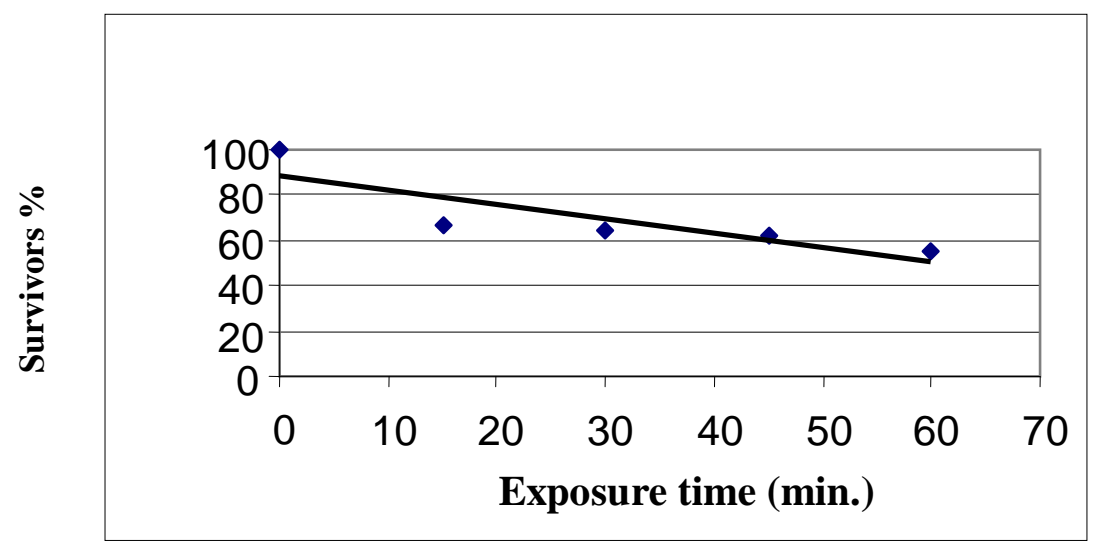

Observed $\quad$ Linear regression

Fig.5. The relationship between the exposure time and the survivors percentage after treating $10 \mathrm{ml}$ S. aureofaciens spore suspension with $0.02 \mathrm{gm}$ NTG.

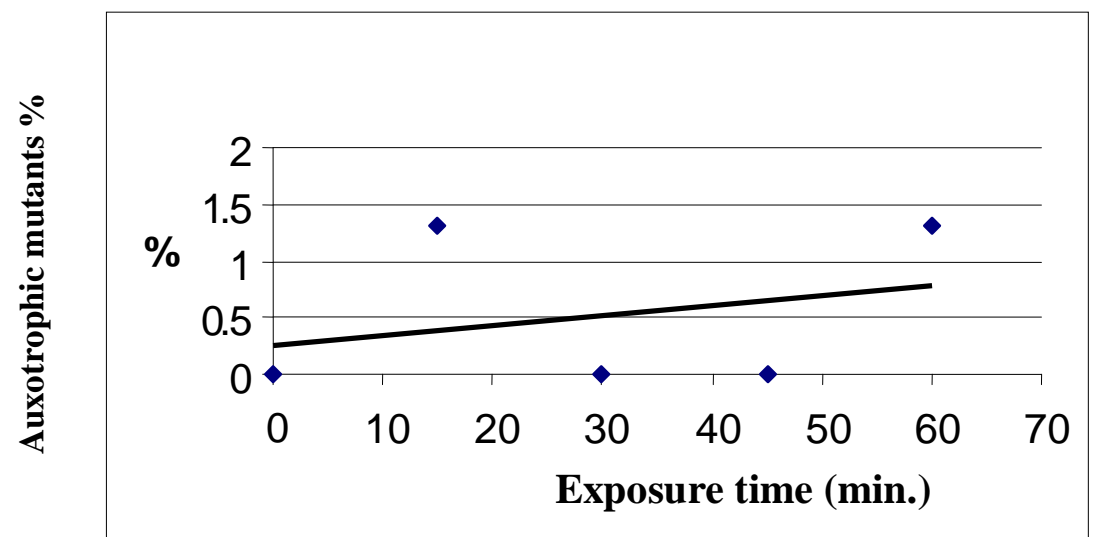

Observed $\bullet \quad$ Linear regression

Fig.6. The relationship between exposure time and auxotrophic mutants percentage produced from treating $10 \mathrm{ml}$ spore suspension $S$. aureofaciens with $0.02 \mathrm{gm}$ NTG. 
Table 4. The relationship between the NTG concentrations, survivals percentage rates and auxotrophic mutants rates.

\begin{tabular}{|c|c|c|c|c|}
\hline $\begin{array}{c}\text { NTG concentration } \\
\text { /10ml }\end{array}$ & $\begin{array}{c}\text { Survivals } \\
\text { rate \% }\end{array}$ & $\begin{array}{c}\text { Number of } \\
\text { isolates }\end{array}$ & \multicolumn{2}{|c|}{ Auxotrophic rate } \\
\hline 0.005 & 83 & 702 & 1 & 0.1 \\
\hline 0.01 & 68 & 1352 & 2 & 0.1 \\
\hline 0.02 & 70 & 442 & 1 & 0.4 \\
\hline
\end{tabular}

Fig.7 The relationship between concentrations and survival rate.

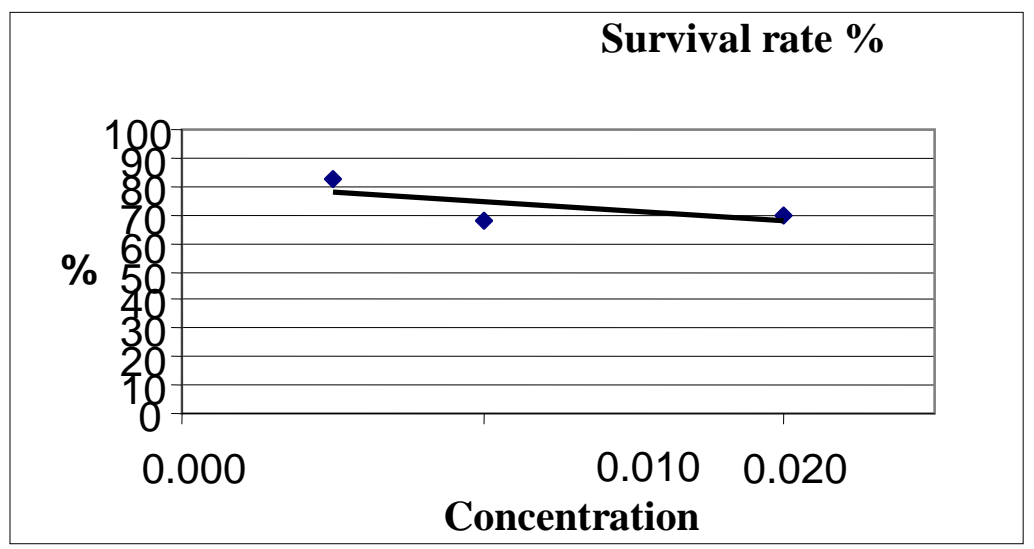

Observed $\quad$ Linear regression

Fig.8 The relationship between concentrations and auxotrophic mutant rate.

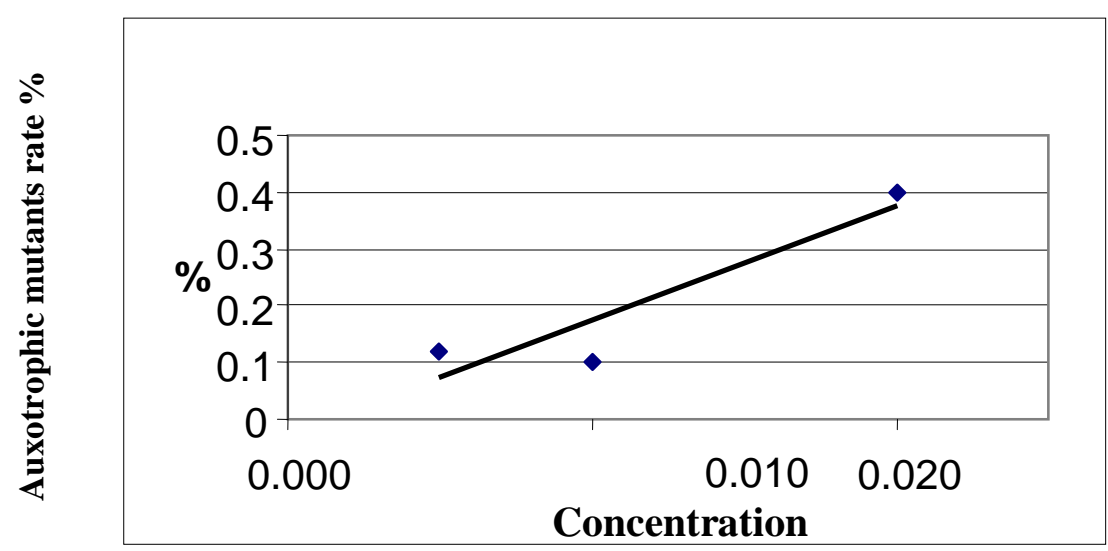

Observed $\quad$ Linear regression 


\section{E. S. Ahmed \& Z. W. Sharawi.}

Fig.9 Total isolation procedure. The dish on the right shows the tiny growth of a mutant colony on minimal medium while the growth of this mutant was better on the complete medium in the left dish; the other (wild type) colonies had the same good growth in both media.

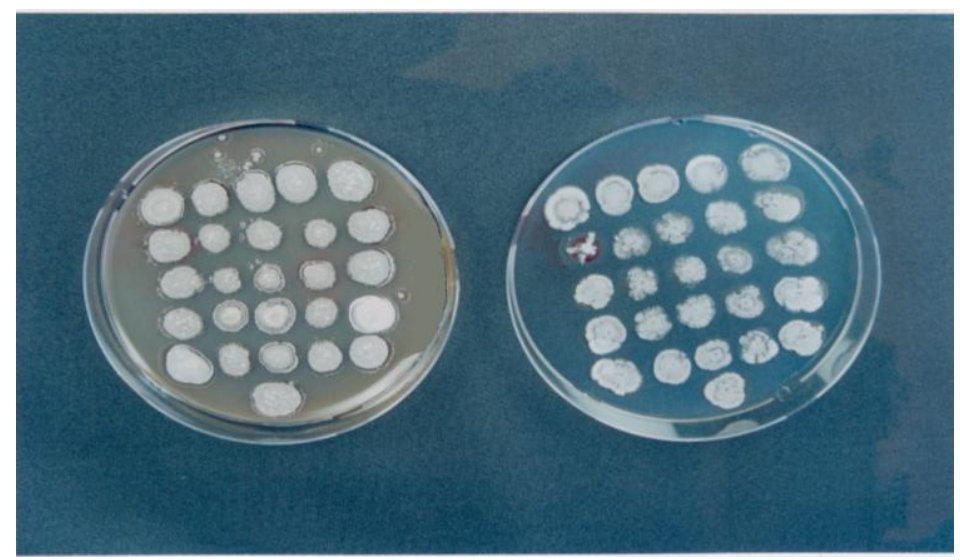

Table5. Auxotrophic mutants classified according to their requirements.

\begin{tabular}{|c|c|c|c|c|}
\hline $\begin{array}{c}\text { Mutant } \\
\text { No. }\end{array}$ & Requirement & $\begin{array}{c}\text { concentration } \\
\mathbf{G m} / \mathbf{1 0 m l}\end{array}$ & Exposure time ( min.) & $\overline{\text { Symbol }}$ \\
\hline & Amino acids: & & & \\
\hline $\begin{array}{l}60 \\
13\end{array}$ & $\begin{array}{c}\text { Tryptophan ,Arginine, Alanine. } \\
\text { Methionine, }\end{array}$ & 0.01 & 60 & $\begin{array}{c}\mathrm{Al}, \mathrm{Ar}, \mathrm{Me}, \\
\mathrm{Tr}-\mathrm{N} 2413\end{array}$ \\
\hline $\begin{array}{c}45 \\
2\end{array}$ & Iso-leusine ,Proline , Glycine. & 0.005 & 45 & $\begin{array}{c}\text { Iso, Pro, } \\
\text { Gly-N1302 }\end{array}$ \\
\hline & Vitamins: & & & \\
\hline $\begin{array}{l}15 \\
22\end{array}$ & $\begin{array}{l}\text { Choline chloride „Pyridoxine } \\
\text { hydrochloride Nicotinic acid. }\end{array}$ & 0.02 & 15 & $\begin{array}{l}\text { Cho, Pyr, } \\
\text { Nic- N3122 }\end{array}$ \\
\hline $\begin{array}{l}60 \\
17\end{array}$ & $\begin{array}{c}\text { Amino benzoic acid ,Aneurine } \\
\text { Choline chloride. }\end{array}$ & 0.02 & 60 & $\begin{array}{l}\text { Ami, Ane, } \\
\text { Cho- N3417 }\end{array}$ \\
\hline & Nitrogen bases: & & & \\
\hline $\begin{array}{l}30 \\
10\end{array}$ & Adenine \& Thymine. & 0.01 & 30 & $\begin{array}{l}\text { Ad, Th- } \\
\text { N2210 }\end{array}$ \\
\hline
\end{tabular}

Fig.10 Determination of auxotrophic mutant requirements; shows this mutant which needs Amino benzoic and choline.

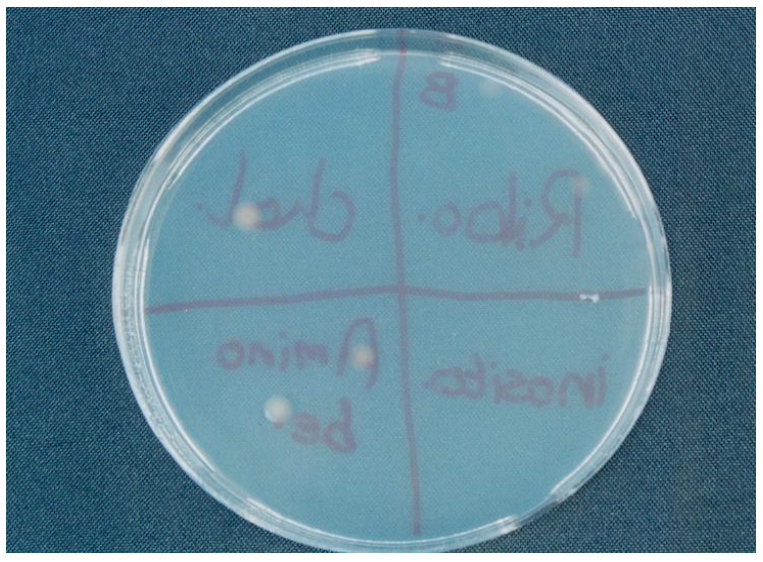


Fig.11 The dry biomass shows the different growth of mycelium after incubating in fermentation date medium, filtering, and drying.

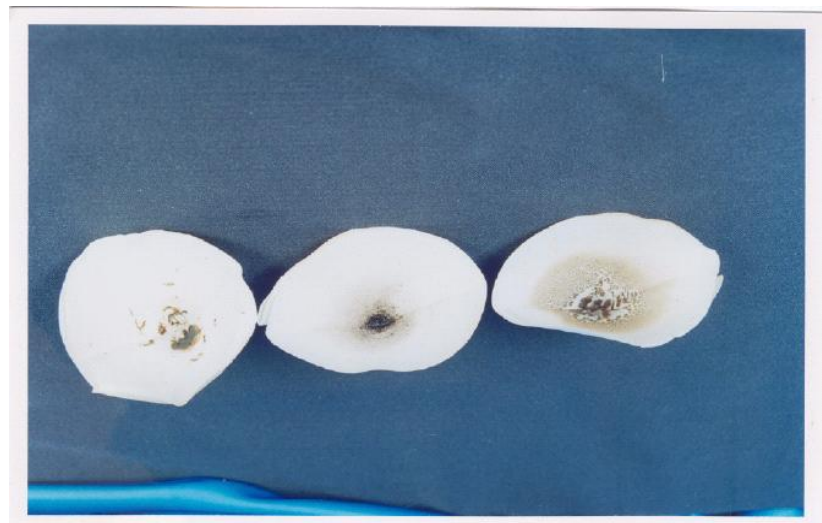

Table 6. The changes associated with mutants after culturing them on fermentation synthetic medium.

\begin{tabular}{|c|c|c|c|c|}
\hline Tested strains & Final pH value * & Dry biomass & $\begin{array}{c}\text { infiltrated } \\
\text { quantity }\end{array}$ & Inhibition zone \\
\hline Control & 4.6 & $0.61 \mathrm{gm}$ & $36.3 \mathrm{ml}$ & $18 \mathrm{~mm}$ \\
\hline Mutant 1 & 5.5 & $0.51 \mathrm{gm}$ & $45 \mathrm{ml}$ & $7 \mathrm{~mm}$ \\
\hline Mutant 2 & 5.6 & $0.59 \mathrm{gm}$ & $42.3 \mathrm{ml}$ & $8 \mathrm{~mm}$ \\
\hline Mutant 3 & 5.9 & $0.59 \mathrm{gm}$ & $43.7 \mathrm{ml}$ & $8 \mathrm{~mm}$ \\
\hline Mutant 4 & 5.6 & $0.52 \mathrm{gm}$ & $43.3 \mathrm{ml}$ & $7.7 \mathrm{~mm}$ \\
\hline Mutant 5 & 5.6 & $0.51 \mathrm{gm}$ & $44 \mathrm{ml}$ & $7.5 \mathrm{~mm}$ \\
\hline
\end{tabular}

* Initial $\mathrm{pH}$ value of the synthetic fermentation medium was adjusted to 6.0.

The mutant strains were defined like this:

Mutant 1: Isolated under concentration $=0.005$, exposure time $=45 \mathrm{mins}$.

Mutant 2: Isolated under concentration $=0.01$, exposure time $=30$ mins.

Mutant 3: Isolated under concentration $=0.01$, exposure time $=60$ mins.

Mutant 4: Isolated under concentration $=0.02$, exposure time $=15$ mins.

Mutant 5: Isolated under concentration $=0.02$, exposure time $=60$ mins. 
Fig12. The differences in inhibition zone created by the wild type and other mutant types from Streptomyces aureofaciens on a dish cultured with Staphylococcus aureus.

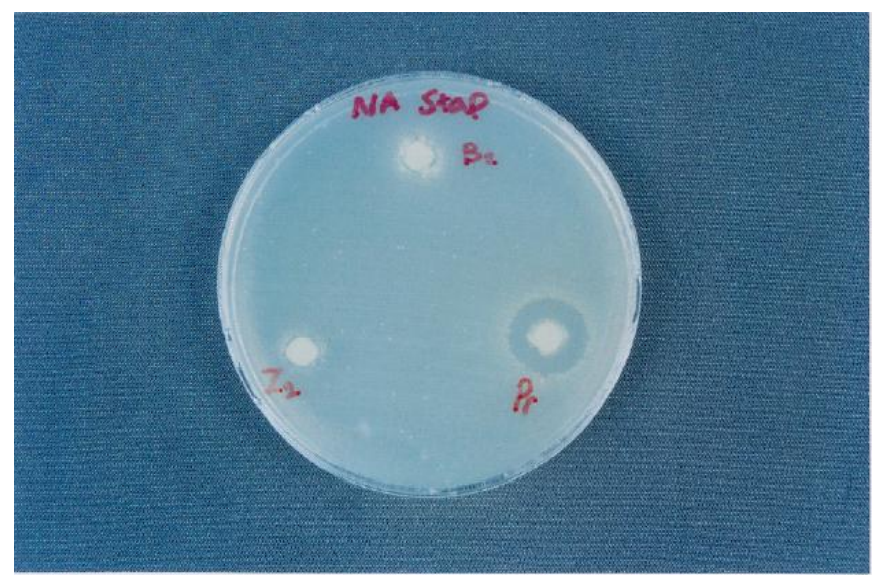

\section{Acknowledgment}

We are grateful to Prof. Dr. Nabih Abdulrahman Baeshin \& Dr.Mohammad Gurban Geshari from Microbiology department in King Abdulaziz University for supplying Streptomyces aureofaciens from National Collections of Industrial, Food and Marine Bacteria LTD, England. as well as Fatina Al- Hrtani for supplying Staphylococcus aureus and Escherichia coli. To King Abdulaziz for Science and Technology (KACST) for their financial support.

\section{References}

1. Abou-Zeid, A. A., Baeshin, N. A. and Baghlaf, A. O. (1990). The formation Of Oxytetracycline in a date-coat medium. Bioresource Technology, 37,179-84.

2. Abou-Zeid, A. A., Baeshin, N. A. and Baghlaf, A. O. (1992). Use of Date products in production of Oxytetracycline by Streptomyces rimosus.Biosci.Biotech. Biochem. 57(6): 987-988.

3. Abou-Zeid, A. A., Baeshin, N. A. and Baghlaf, A. O. (1993). Utilization of Date products in Production of Oxytetracycline by Streptomyces rimosus. Zentralb. Mikrobiol.148: 333-341.

4. Baeshin, N.A., and Sabir, J.M., 1984. Genetic studies with Aspergillus terreus. Research Sci., K.A.U., 215-224.

5. Baeshin, N. A., Abou-Zeid, A. A. and Baghlaf, A. O. (1992). The formation of
Oxytetracycline in a Date Medium by Mutants of Streptomyces rimosus Included by Chemical Mutagens. Bioresource Technology. 42. 177-188.

6. Baeshin, N.A., Abdel Rahman, Nadia, A. and Al-Tawaty, N.H.,(1987). Introduction of mutation in Saccharomyces. Research Sci., K.A.U., 225-234.

7. Bentley, Chater K. F., Cerdeño-Tárraga A.-M. , Challis G. L.D.A. (2002). Complete Genome sequence of the model actinomycete Streptomyces coelicolor Nature: 417 A3 (2)., 141-147.

8. Chopra, L. and Roberts. (2001). etracycline Antibiotics: Mode of Action, Applications, Molecular Biology, and Epidemiology of Bacterial Resistance. Microbiol Mol Biol Rev. 65(2):232- 260.

9. Col, N. F., and O'Connor. R. W. (1987). Estimating worldwide current antibiotic usage: Report of task force 1. Rev. Infect. Dis. 9:232-243.

10. Dairi, T., Aisaka, K., Katsumata, R., and Hasegawa M. (1995). A self-Defense gene homologous to tetracycline effluxing gene essential For antibiotic production in Streptomyces aureofaciens. Biosci. Biotechnol Biochem. 59:1835-1841.

11. Finch, R. G. (1997). Tetracyclines. In F. O'Grady, H. P. Lambert, R. G. Finch and D. Greenwood (ed.), Antibiotic and chemotherapy. 469-484.

12. Fincham, J.R.S., Day, P.R. and Radford, A., (1979). Fungal Genetics, University of California Press.

13. Liutskanova DG, Stoilova-Disheva MM, and Peltekova VT. (2005). Increase in 
tylosin production by a commercial strain of Streptomyces fradiae. Prikl Biokhim Mikrobiol. 41(2):189-93.

14. Matseliukh, BP.; Lutchenko, V.A. and Polishchuk, LV. (2003). Synthesis of carotenoids by mutant strains of Streptomyces globisporus 1912.Mikrobiol Z. 65(6):24-30.

15. Petruk, TV.;Biliavs'ka, L.O, Kozyryts'ka VIe.; and Mukvych, MS. (2004). Increasing biosynthesis of averm-ectins of Streptomyces avermitilis UCM Ac 2161 under the effect N-methyl-N'-nitro-Nnitrosoguanidine. Mikrobiol Z.66 (6):24-30.

16. Prescott, J. F. and Baggot, J. D. (1994). Antimicrobial therapy in veterinary medicine.. (Iowa State University Press, Ames,) pp. 3-10.

17. Riesbeck K, Bredberg A, and Forsgren A. (1990). Ciprofloxacin does not inhibit mitochondrial functions but other antibiotics do. Antimicrob Agents Chemother. 34(1): 167-9

18. Stryzhkova, H.M., Koopeiko, O.P., Lavrinchuck, Via., Bambura, OI. and Matseliukh, B.P.(2002). Spontaneous and induced variability of -Streptomyces aureofaciens - chlortetracycline producer. Mikrobiol Z. 64(4):19-23.

19. Wang, Z., Wang, G., Yang, J., Guo, L. and Yu, Y. (2003). Activation of Protein kinase $\mathrm{A}$ and clustering of cell surface receptors by N-methyl-N'-nitro-N- nitrosoguanidine are independent of genomic DNA damage. Mutat. Res. 528:29- 36.

20. Unknown. Reviewed 12.2005. http://edicion-micro. usal. es/web /educativo/m_especial/11ctexto4.htm 


\section{تكوين التتراسايكلين في بيئة التمر بواسطة طفرات من ستربتومايسيس أوروفاشينز مستحدثة بيعض المطفرات الكيميائية.}

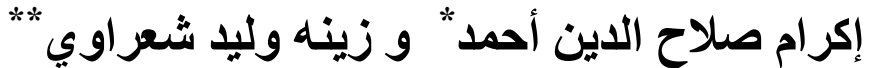

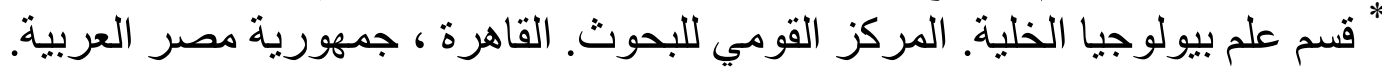
*** قسم الأحياء. كلية العلوم. جامعة الملك عبد العزيز. جدة العرة ، المملكة العربية السعودية.

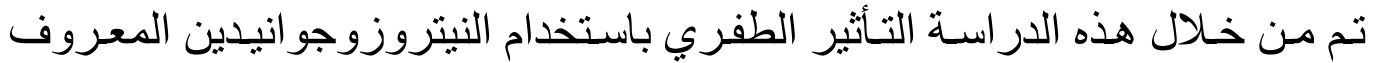

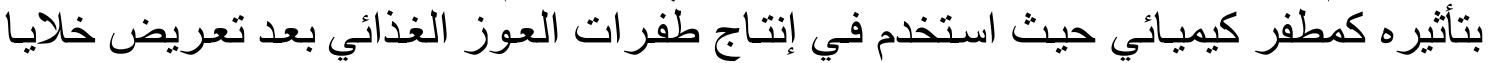

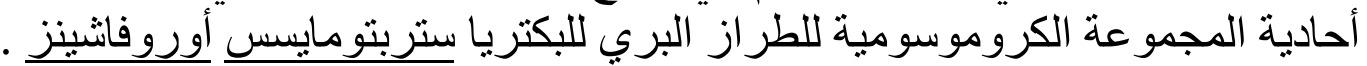

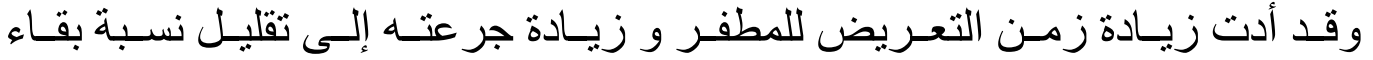

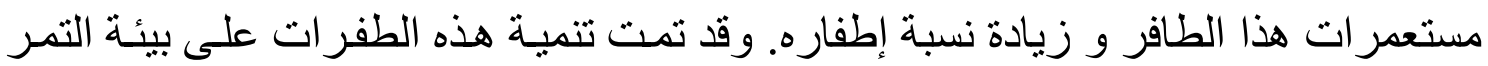

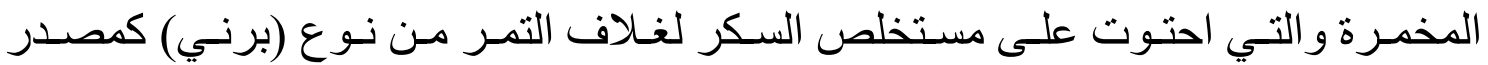
للكربون. وقد تم قياس الوحدات التالية:

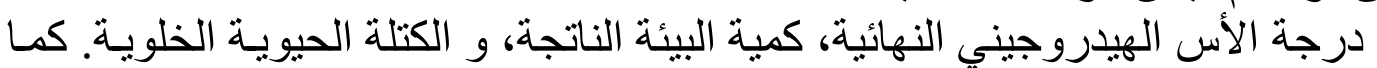

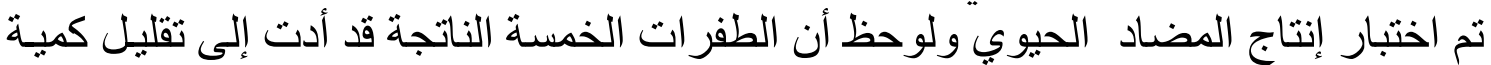

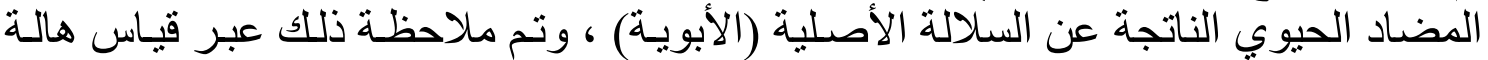

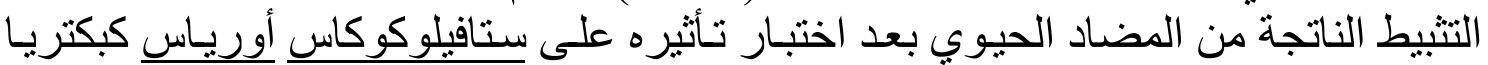

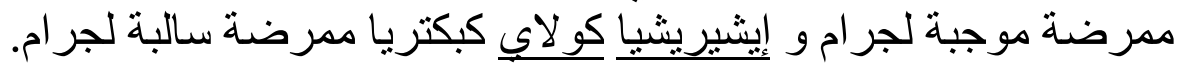

